DOI: https://doi.org/10.47405/mjssh.v6i9.1058

\begin{tabular}{|c|c|}
\hline 4 & Malaysian Journal of Social Sciences and Humanities (MJSSH) \\
\hline $\begin{array}{l}\text { Malaysian Juoural of } \\
\text { Social ccciecces and }\end{array}$ & Volume 6, Issue 9, September 2021 \\
\hline (MJ-sSH) & e-ISSN : 2504-8562 \\
\hline & $\begin{array}{l}\text { Journal home page: } \\
\text { www.msocialsciences.com }\end{array}$ \\
\hline
\end{tabular}

\title{
Building an Effective Branding Strategy: A Study Case of Raiment
}

\author{
Marcellinus Namas Iskandar ${ }^{1}$, Fitri Aprilianty ${ }^{1}$ \\ ${ }^{1}$ School of Business and Management, Bandung Institute of Technology, Indonesia
}

Correspondence: Marcellinus Namas Iskandar (marcellinus_namas@sbm-itb.ac.id)

\begin{abstract}
Since the civilized era, branding has played a very important role in business activities which when people recognize the brand, they have a perceived perception of the object. Seems simple and practical, many people mistakenly think that brand-building is an easy thing to do and therefore many businesses are stuck or even fail because they are not built through the appropriate implementation of strategies. One of which included Raiment, an online platforms-based business which helps people to create or customize clothing products. Having a vision to simplify the process of procuring a clothing product that was previously considered inefficient, concerns started to arise after it was known that the number of sales generated by Raiment for more than 1 year operating did not have any significant progress. In fact, most of the sales generated are still related through relatives such as friends and families. The aim of this research is to help Raiment to be able to assess the related factors in building its brand and also develop the right strategy to be able to create a better brand. External and internal analysis are also used in this research to help see the root of the problems faced by Raiment. The external analysis included is Porter's Five Forces, PESTEL Analysis, and Competitor Analysis. Meanwhile, the internal analysis included is Company Analysis and Brand Audit Analysis. The results of this study indicate that the roots of the problems faced by Raiment are around unclear brand-building guidelines, lack of available budget, lack of knowledge regarding the industry, and also lack of brand marketing efforts. Several solutions were proposed to address the root causes of the problem in developing the Raiment brand, such as creating a brand positioning model to increase brand awareness, building a brand resonance model to build brand loyalty, and also creating a brand value chain model to measure returns from the allocated investment for brand marketing activities. The results of this research can also help other businesses in improving and strengthening the existence of their brands, especially in the Indonesian market. With a note, further studies related to the garment/convection industry need to be carried out due to the growing trend.
\end{abstract}

Keywords: garment business, convection business, brand audit, branding strategy

\section{Introduction}

The ideas of the global fashion industry which most people have been familiar with right now are actually the products of modern times (Steele, 1998). Prior to the mid-19th century, most clothing was tailor-made (by hand) for individuals either as a home product or by order from tailor to tailor. At the beginning of the 20th century, with the emergence of new technologies such as sewing machines and the internet, it was only then that the rise of global capitalism, the development of factory production systems, and the flow of the fashion movement increased drastically. Digital transformation, with the 
development of data analysis that is more sophisticated, has created marketing strategies that are more customer-centric which then enable the fashion industry market players to create segmented and targeted messages for a brand's customers. As a result, fashion companies are able to respond to the needs and desires of their customers more precisely and accurately in accordance with the values that they want to project from each brand.

Since the civilized era, branding has played a very important role in exchanging activities or what we usually call business activities. Although at that time there was a gradual transition from more utilitarian provision of information regarding origin and quality in order to reduce risk and uncertainty during earlier periods of civilization (transactional), to the addition of more complex brand characteristics through time which are related to image building and include status / power, inherent value and finally, the development of brand personality in terms of transactional (Moore \& Reid, 2008), the function offered is actually the same; People recognize the brand, they have a perceived perception of the object (CodeCrater, 2017).

Even with all the limitations both in terms of communication and logistics, fashion marketers in previous centuries have their own way of ensuring that what they want to offer through a brand can be channelled even though the concept is basically the same: create a demand, qualify it, and retain it. Here are some examples of some of the media used by fashion marketers in the previous century to build their fashion brands: Pandoras (fashion dolls) which are used to display latest styles and are sent across oceans and countries from Paris, London, and New York to ensure that other tailors could copy and reproduce the outfits; Fashion Plates which is a portrait that was used to illustrate and communicate a style of clothing to a potential buyer (Laver, 1995); The Boutique was built for attention in passing which later became the origin of "seasonality" and "novelty" of fashion.

In this rapidly changing era, technological disruptions that continue to emerge as a result of the development of the industrial revolution have changed the way we live as humans and also operate various business systems. Technology seems to be an important part of human life which is very difficult to let go of and is also an important reason behind the rapid growth of the quality of human life because of its ability to facilitate the distribution and exchange of information (Setiawan, 2017). Apart from the negative and positive impacts, of course there will be shifting behaviors caused by this phenomenon, including how business units offer value and experience through the brands they create.

A transformation of marketing is taking place as we consumers in modern times spend more time in front of digital device screens than ever before. The real-time interactions that occur between brands and humans through digital media have changed the nature of marketing. "The only thing that hasn't changed is the creativity and the passion from brands that have really helped build loyalty and emotion" said Tanya Cordrey, Guardian News and Media's chief digital officer, in a panel discussion with five top marketers and digital chief officers. Three areas that have changed drastically due to the digital technology emergence are the speed, relevance, and reach of campaigns. For example, in the days before the advent of digital marketing tools, not a single brand could publish an ad in a matter of minutes and by targeting the ad specifically to people of a certain age, a certain gender, and a certain interest that covered one country. On the other hand, this is the basic thing to do with digital marketing

Brand is often interpreted as a name or marker of a product / service used by companies in running their business, while in fact there are many more meanings contained in the meaning of the word (Radji, 2008). A brand can be said to be the same as an image, the same as the face of a company, the same as a telling experience that is embedded in consumers, and is not only limited to the name or logo of a company. Brand can be defined as the overall consumer experience that differentiates an organization or product from its competitors from the consumer side (Kohli \& Jaworski, 1990).

Unlike conventional businesses in general, many current businesses rely on online-based platforms as the main communication line that connects them with consumers. In Indonesia, there have been many business sectors that have been completely disrupted and changed with the presence of new emerging technologies (Kituyi, 2021) such as Gojek in the transportation sector and Traveloka in the tourism 
sector. From this we can see the fact that online activities in people's lives are very important and real. It's also likely to change when, where, and how people perceive the brand of a business.

Seems simple and practical, many people mistakenly think that building a business is an easy thing to do. Therefore, many businesses are stuck or even fail because they are not built on a strategy or maybe built through the implementation of inappropriate strategies. According to the records of the Ministry of Cooperatives and Small and Medium Enterprises, the number of entrepreneurs in Indonesia increased from $1.67 \%$ previously to $3.10 \%$ of the total population of Indonesia, which is currently 225 million people. But on the other hand, Research from the University of Tennessee in 2013 said that $25 \%$ of businesses fail after 1 year, then $35 \%$ after the second year. This failure was even greater in the third year, namely $44 \%$. This means that if there are 10 businesses, only 2-3 businesses will survive the third year (Malisa, 2020). In addition, based on the infographic from CB Insights, it is stated that 1 in 7 business units fail because they don't have an effective marketing strategy, including branding.

In this study, the researcher wishes to explore more deeply related to an effective branding strategy approach to Raiment_id, an online start-up company engaged in clothing production. Having a vision to simplify the process of procuring a clothing product that was previously considered inefficient, Raiment.id offers the best service and customer experience by utilizing internet technology. Through this research also the author hopes to increase the brand presence of Raiment, see important factors that need to be considered in building an effective brand, and also most importantly, it is hoped that Raiment.id can increase its sales level. The author believes that with technology, everything is expected to change for the better, to a system that is easier and more profitable, but that all can only happen if we optimize and take advantage of the existing opportunities appropriately.

\section{Literature Review}

\section{Brand Audit Analysis}

Brand audit is a comprehensive assessment of a brand to discover the source of its brand equity. In contrast to a marketing audit, a brand audit is an assessment that focuses more on the consumer, or the external side, to see the health of a brand and provide suggestions on how to improve and increase the equity of a brand (Keller, 2013). Brand audit is a reflection of the quality of the current brand position which is seen based on the perception of the relevant target audience/consumers (Staisch, 2007). To conduct a brand audit, an understanding of the source of brand equity is needed from both the company's point of view and from the consumer's point of view. By conducting brand audits regularly, marketers can find out the condition and performance of the brands they have created and for this reason brand audits are one of the useful approaches as they set up marketing plans (Keller, 2013). This brand audit will then be divided into three parts of assessment, namely brand elements, brand inventory, and brand exploratory

\section{Brand Elements}

According to the American Marketing Association (AMA), Brand Elements are defined as characteristics, features, or traits that differentiate a brand from others (Keller, 2013). As stated earlier, the main purpose of these brand elements is to create uniqueness in a competitive market. These elements can take various forms such as slogans, logos, taglines, names, and packaging (Ranjhaa, 2021). Moreover, these brand elements must also have certain characteristics that must be considered so that those elements can reflect their main purpose. The process of creating brand elements is certainly an important part of a company's marketing mix. In general, there are 6 characteristics that are commonly used to determine brand elements for a business, namely memorability, meaningfulness, liability, transferability, adaptability, and protect-ability (Ranjhaa, 2021). 


\section{Brand Inventory}

Brand inventory is a collection of things that have been created in order to support the marketing of certain business's products or services (Mills, 2020). The main purpose of a brand inventory is to provide an up-to-date comprehensive profile of how all products and services sold by a company are marketed and branded. This can include brand elements, trademarks, inherent product attributes, pricing, communications, and any other relevant marketing activity related to a brand (Keller, 2013).

\section{Brand Positioning}

Brand positioning is the act of designing an offering that is owned by a company so that it is located in a different place from competitors in the minds of the target market (Keller, 2013). A good brand positioning can help marketers to create marketing strategies by creating a series of activities that are in line with the meaning and purpose of a brand, the uniqueness of a brand, or how the brand can be said to be different from its competitors. The basic concept of brand positioning lies in understanding who the target market of the brand is, who are the main competitors of the brand, how the brand is similar to its competitors, and how the brand is different from its competitors (Keller, 2013).inventory is a collection of things that have been created in order to support the marketing of certain business's products or services (Mills, 2020). The main purpose of a brand inventory is to provide an up-to-date comprehensive profile of how all products and services sold by a company are marketed and branded. This can include brand elements, trademarks, inherent product attributes, pricing, communications, and any other relevant marketing activity related to a brand (Keller, 2013).

\section{Brand Exploratory}

Brand exploratory is a research approach that focuses on understanding what consumers think and feel about a brand and how they act toward that brand. Brand exploratory is carried out to be able to dig deeper into what are the sources of brand equity and if possible, what are the barriers that hinder it (Keller, 2013). According to Kevin Lane Keller, who is a Professor of Marketing at the Tuck School of Business at Dartmouth College, a number of preliminary activities are usually carried out to support an exploratory brand such as prior research studies regarding the company or qualitative research on internal peers to gain insights of their beliefs about consumer perceptions towards the brand.

\section{Brand Awareness}

Brand awareness is a marketing term that describes how deep the level of recognition of customers is to products or services offered by a brand. Creating brand awareness is an essential first step in promoting a business (Kopp, 2021a). Businesses that have a high level of brand awareness are likely to generate higher sales as well because consumers / customers will be more likely to buy a brand whose name sounds familiar compared to those that don't.

\section{Brand Loyalty}

By definition, brand loyalty is a positive association embedded in a product or brand by the customers. Customers who have loyalty to a certain brand are usually demonstrated on repeat purchases regardless of competitors' attempts to divert them (Kopp, 2021b). Many products from major brands are present in a highly competitive market which is filled with competing new and old products, many of which are difficult to distinguish. This is where finally those companies do a lot of strategies to maintain customers with brand loyalty. Before the internet, the most common way to build brand loyalty was by interacting with salespeople and customers. Now, with the internet that provides direct access to thousands of customers without a salesperson as an intermediary, building brand loyalty is such a subtle thing to build. There are also several drivers to brand loyalty which are brand satisfaction and brand competence (Setyawan \& Kussudiyarsana, 2015). 


\section{Perceived Quality}

By the definition, perceived quality is customers' perception of the overall quality or superiority of a product or service compared to alternatives and with respect to its intended purpose (Keller, 2013). It is the customer's own perception of the desirability of a product or service compared to the competitors' product or service (Kopp, 2020). Perceived quality is often measured by the price that customers are willing to pay for a product / service and most of the time the pricing of products/services also takes perceived quality into consideration.

\section{Conceptual Framework}

This study departs from current business issues, which is mainly focused on the field of branding and marketing. Starting from external analysis consisting of PESTEL analysis, a tool to help marketers to analyse macro-environmental factors that have an impact on Raiment's company, then Competitor Analysis which helps to see the position and position of the competitor's brand, and Porter's Five Forces Analysis which helps analyse the competitive environment from the business industry. After that there is also an Internal Analysis which helps analyse the internal conditions of the Raiment company, starting from the Business Model Analysis of Raiment and also the Brand Audit which analyses Raiment's level of Brand Awareness, Brand Loyalty, and Perceived Quality as a business.

Both these studies will generate a more validated SWOT Analysis which will then become the basis for the next analysis which is the Root Cause Analysis. After going through the process of understanding what is the root cause of the existing business issue, only then will it be elaborated on what are the solutions to these issues and what implementation plan is right for Raiment to solve them.

Figure 1: Conceptual Framework

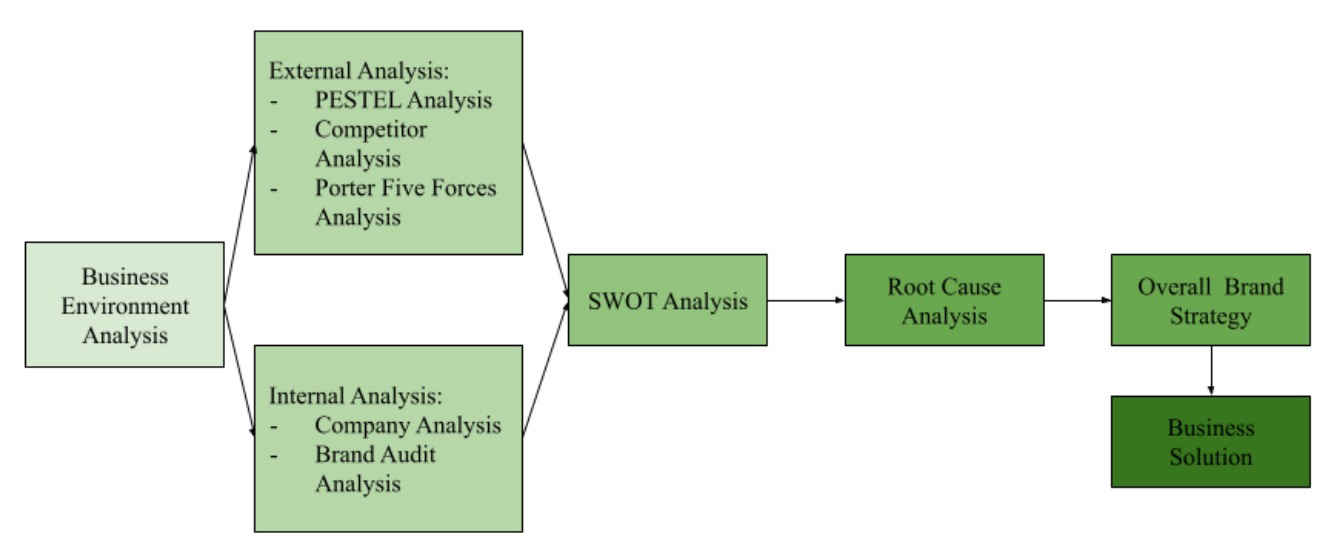

\section{Methodology}

\section{External Analysis}

As a process that helps to analyze changes made to the industry and broader world that could affect our business operations, an external analysis is needed to be conducted. Through external analysis, business entities can anticipate and adapt to changes that occur in the world, which then open up opportunities to rise above the competition (Indeed, 2020). This external analysis will later consist of 3 main components, which are the PESTEL, Porter Five Forces, and Competitor Analysis. 


\section{Internal Analysis}

As part of a thorough examination of a company's internal components, an internal analysis is needed to be conducted. Internal analysis enables the company decision-makers to accurately identify areas for growth or revision to form a practical business strategy or business plan. (Indeed, 2021). The data generated by an internal analysis is important because it can be used to develop strategic planning objectives to sustain and grow the business (Williams, 2019). In this research, the internal analysis will consist of brand audit analysis and company analysis.

\section{Survey Method}

As a part of the brand audit analysis, this research will be using a survey method with a questionnaire as a tool to evaluate the brand equity of Raiment towards its target market and customers. The questions used in this questionnaire will be developed based on the aspects that will be examined in the brand audit which is brand awareness, brand loyalty, and perceived quality from Raiment brand. The purpose of this survey is to validate the brand equity contained in Raiment so that it can be one of the factors examined in the brand audit.

\section{Data Collection}

For the data collection part of this quantitative approach, a purposive sampling technique will be used, which means that the respondents selected to fill out this questionnaire were not chosen at random but were addressed to those who are likely to use Raiment's services as well as those who are included in the customer database from Raiment. Currently, Raiment's target market is those who are members of groups/organizations which involve the process of procuring clothing in large quantities (>12) such as association organizations on campus or retail fashion business (B2B). In addition, Raiment also targets individuals (B2C) who have the desire to use custom clothing manufacturing services but in smaller quantities $(<12)$. Since Raiment's customer database still does not exceed the sample size which can be said to be sufficient for problem-solving marketing research according to Malhotra (2006), Raiment will use a modest number of respondents.

\section{Data Analysis}

The results obtained from the survey will then be analyzed using descriptive statistics to interpret these findings into further analysis related to Raiment's brand audit analysis. In short, descriptive statistics is an approach that summarizes and describes the characteristics of a dataset that is considered to represent a sample of a population (Hayes, 2021c). The results will also be displayed in the form of charts and also graphics to help demonstrate the data in a way that is easy to understand.

\section{SWOT Analysis}

After conducting an external and internal analysis of Raiment's business, the factors that later become strengths, weaknesses, opportunities, or threats from previous results will later be summarized in the SWOT table. Strengths and weaknesses are derived from the previous internal analysis of the business and can be used to capture a summary of internal audits that have been carried out, while opportunities and threats are derived from the previous external analysis of the business. The main objective of this analysis is to develop a full awareness of the factors involved in making a business decision.

\section{Root Cause Analysis}

In this root cause analysis, the researcher will dig deeper into the main causes of the problems currently hindering Raiment in developing its brand. For this root cause analysis, the researcher will be using Fishbone Diagram or Ishikawa Diagram is a method used to see causes of an event and is often used in manufacturing and product development to see different steps in a process (Hayes, 2021). By using the 
results from the SWOT analysis, the researcher will then look for alternative solutions to the problems that have been identified through the fishbone diagram.

\section{Result}

\section{PESTEL Analysis}

\section{Root Cause Analysis}

The following are the results of a root cause analysis carried out using a fishbone diagram to see the source of the problem that Raiment was facing:

Figure 2: Fishbone Diagram

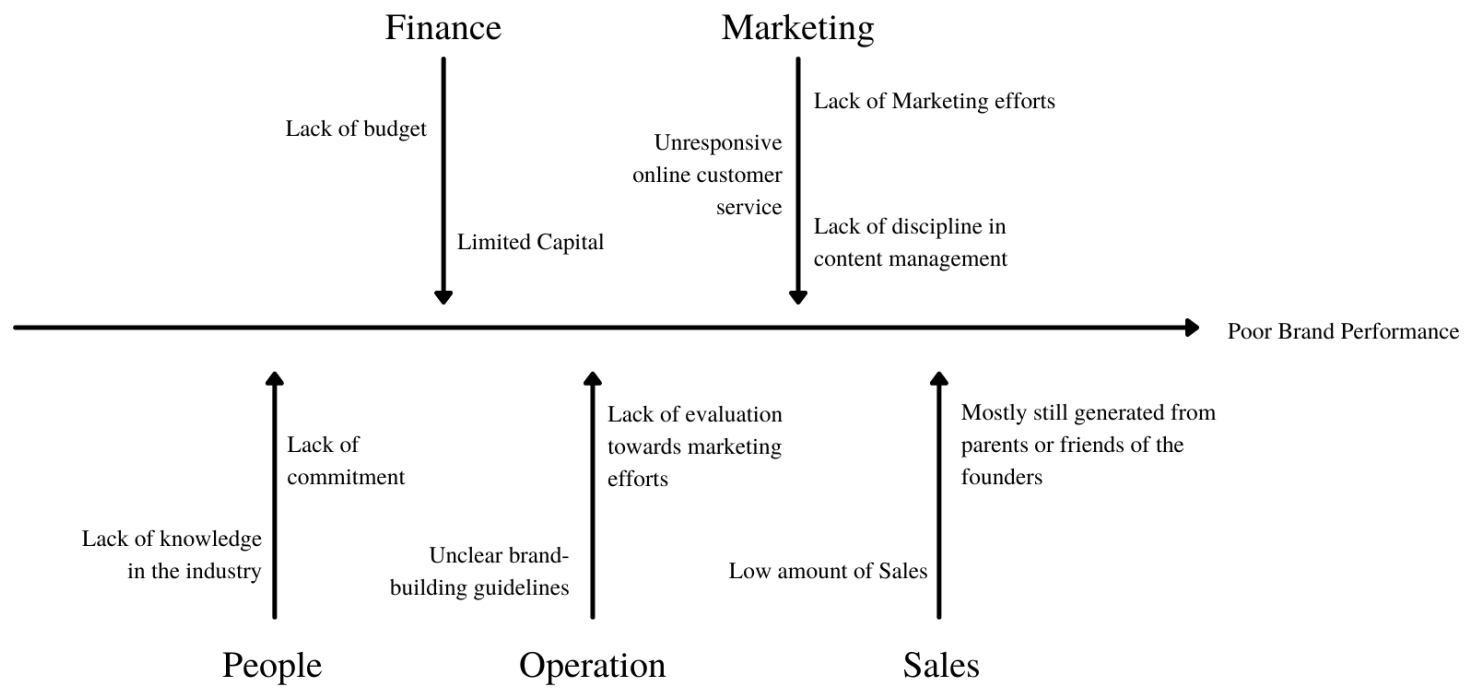

From the root cause analysis, the fishbone diagram above shown that there are 5 roots which are becoming the main constraints of Raiment to improve its brand. The root causes include: lack of knowledge regarding the industry in the people, lack of budget in finance, unclear brand-building guidelines in the operation, lack of brand marketing efforts in marketing, and lastly low number of sales. Based on these root causes, in the next chapter, the researcher will discuss more onto useful solutions which will improve Raiment's brand performance.

\section{Discussion}

\section{Create a Brand Positioning Model}

To overcome unclear brand-building guidelines and lack of marketing efforts, the researcher suggests creating a brand positioning model as the first building block of the 3 stages of the brand-building process for Raiment brand to be able to develop a feasible and strong brand. Brand positioning is the most important core of marketing strategy (Keller, 2013) as in the brand positioning model, Raiment will focus on the process of making integrated marketing to have a competitive advantage in the market. By the word "position" here means a place in the minds of the target market so that they have their own image of what is their reason for buying the product/service offered by a brand. By doing the right brand positioning, Raiment can create a clear marketing strategy so that the core values or messages that Raiment wants to convey can be conveyed properly. 


\section{Create a Brand Resonance Model}

To overcome the lack of discipline in content management, lack of marketing efforts, and the large number of sales that are still generated from relatives, the researcher suggests that Raiment create a brand resonance model as the second building block of the 3 stages of the brand-building process in which Raiment brand is expected to develop. can create an intense and active brand loyalty relationship. The brand resonance model is a continuation of the previous stage so that in the manufacturing process, Raiment brand will be focusing on to implement the competitive advantage discovered previously into a new cycle to create strong relationships with customers to turn it into a value in brand equity. In this process, Raiment will focus on creating a brand marketing strategy that is consistent, has a clear basis, is purposive, and is able to generate positive response and loyalty.

\section{Create buyers' persona for effective brand marketing approach}

To overcome the lack of marketing efforts and low number of sales, the researcher suggests that Raiment should create a buyers' persona to help build detailed descriptions and better understanding through fictional persona which represents a certain population of the target market. This is done with the aim of understanding more deeply related to behavior and the tendencies of the target customers so that Raiment can provide solutions that really help their needs. As part of customer relationship management, by creating buyers' personas Raiment can also carry out a more effective brand marketing approach to each of the existing customer segments as Raiment will be able to create a more personalized and effective brand marketing strategy.

\section{Build a Brand Value Chain Model}

To overcome the lack of budget and lack of evaluation towards marketing efforts, the researcher suggests Raiment to create a brand value chain model as the last building block in 3 stages of the brand-building process where in the brand value chain model, Raiment will be able to see and review effectiveness and impact of the expenditures/budget from the previous brand marketing efforts. In the brand value chain, there are 4 value stages which are the Marketing Program Investment, Customer Mind-Set, Market Performance, and Shareholder Value, which are then influenced by 3 types of multipliers which are the Program Quality, Marketplace Conditions, and Investor Sentiment. As a form of activity in building a brand value chain model, Raiment will conduct periodic brand audit analysis which will evaluate the marketing program investment, customer mind-set, and also market performance. Raiment is not expected to make an analysis related to shareholder value as Raiment is still fully owned by the founders and has no investors.

\section{Join local garment/convection communities}

To overcome the lack of general knowledge regarding the industry, the researcher suggests Raiment to join local garment/convection communities in order to find out about conversations and updates about the world of convection. By joining local convection communities such as the Bandung Convection Community and the Bandung Sablon Community, it creates many new opportunities to add general knowledge regarding the product and the garment industry as a whole. Although it is possible that there will be competitors from Raiment in the community, the discussion in the community will be much more profitable for the Raiment founders (whose business scale is still relatively small) because in a community there tend to be many discussions and also things to share related to the industry. garments that are up to date so that founders can make strategic decisions that are profitable for the Raiment brand. Joining a community also indirectly increases Raiment's network which in the future can be useful for developing Raiment as a business.

\section{Find ways to increase capital}

To overcome the root cause of the lack of budget, the researcher suggests that Raiment is looking for several alternative ways to increase capital which will enable Raiment to grow as a business. Some 
ways that can be done for this are by looking for investors and credit loans from banks. This is a crucial step because with little capital, the progress of the development of a business will also move slowly.

\section{Look after the required business legal documents}

To overcome the root cause of the lack of work commitment, the researcher suggests Raiment to look after the required business legal documents because in it there will be a process of making founders' agreements which are the core of the goals and commitments of the founders when running a business. This is because, based on the results obtained from the previous internal analysis, it can be seen that most of the executors of the business did not have a maximum amount of work commitment to build Raiment as a growing business mostly due to the fact that the founders at that time were prioritizing other things rather than developing Raiment as a business and none of them wanted to straighten this out on the grounds assuming that there would be a broken relationship between them.

\section{Hire necessary Human Resources}

To overcome the unresponsive online customer service, the researcher suggests that Raiment should hire the necessary human resources such as the IT support to help fix technical problems that prevent the Raiment website features from operating optimally and also the admin who is in charge of responding to all customer responses throughout the online channels used by Raiment. Judging from the strength of Raiment who was previously used to a clear division of jobs and roles (despite the relatively small number of members), having 1 or 2 new roles/characters in the business process should not prevent Raiment from being able to increase productivity and better work output. again. "Hire" here does not only mean hiring permanent or full-time employees, but the option is also open for freelance services and also part-time workers as Raiment has limited capital.

\section{Conclusion}

The objective of this research was to assist Raiment to build a strong and recognizable brand by assessing the brand equity that Raiment currently has and to propose solutions that Raiment is going to need to build an effective branding strategy. To fulfill these objectives, the researcher conducted external and internal analysis, including a brand audit analysis conducted through a quantitative approach with a purposive sampling method given to individuals belonging to the target market of Raiment. After a comprehensive process of analysis, it is found that Raiment's poor brand performance was caused by several root causes, such as lack of budget, lack of knowledge in the industry, unclear brand-building guidelines, lack of brand marketing efforts, and low number of sales. From those root problems, the researcher suggests that Raiment implement several solutions such as building a brand positioning model, brand resonance model, and brand value chain model as a three-part process of brand building. In addition, the researcher also suggests several solutions regarding general business development such as join local garment communities, find ways to increase capital, look after the required business legal documents, and hire necessary human resources.

The results of this research could be implicated in helping other businesses in the same industry as a learning material in assessing and building their branding strategy, especially to those who are targeting the Indonesian market. Since there are fast-moving changes in the market and in the general industry due to the pandemic, further study about the most recent trends and internal situations of each company are highly recommended. As for the academic purposes, it is recommended that the future studies include strategies regarding the growth and sustainability of brand equity since it will become the next step of the complete and whole brand building process. 


\section{References}

CodeCrater. (2017, August 11). A Brief History of Branding and Why You Need It - CodeCrater. https://codecrater.com/blog/brief-history-branding-need/

Hayes, A. (2021a, June 29). Ishikawa Diagram Definition. https://www.investopedia.com/terms/i/ishikawa-diagram.asp

Hayes, A. (2021b, August 3). Descriptive Statistics Definition. https://www.investopedia.com/terms/d/descriptive_statistics.asp

Indeed. (2020). What Is External Analysis? Definition and Examples | Indeed.com. Indeed. https://www.indeed.com/career-advice/career-development/external-analysis

INDEED. (2021). How to Conduct a Thorough Internal Analysis | Indeed.com. https://www.indeed.com/career-advice/career-development/internal-analysis

Keller, Kevin L. (2005). Strategic Brand Management Process. Moderne Markenführung, 83-101. https://doi.org/10.1007/978-3-8349-4541-9_3

Keller, Kevin Lane. (2013). Strategic Brand Management Building, Measuring, and Managing Brand Equity Global Edition.

Kituyi, M. (2021). Technology and Innovation Report 2021. https://unctad.org/system/files/officialdocument/tir2020_en.pdf

Kohli, A. K., \& Jaworski, B. J. (1990). Market Orientation: The Construct, Research Propositions, and Managerial Implications. Journal of Marketing, 54(2), 1-18. https://doi.org/10.1177/002224299005400201

Kopp, C. (2020, December 1). Perceived Value Definition. https://www.investopedia.com/terms/p/perceived-value.asp

Kopp, C. (2021a, February 23). Brand Awareness Definition. https://www.investopedia.com/terms/b/brandawareness.asp

Kopp, C. (2021b, July 1). Brand Loyalty Definition. https://www.investopedia.com/terms/b/brandloyalty.asp

Laver, J. (1995). Costume and fashion : a concise history. Oxford University Press.

Malisa, A. N. (2020). Analisis aktor Penyebab Kegagalan Bisnis Online. 1-118.

Mills, J. (2020, July 28). What Is a Brand Inventory? | Element Three. https://elementthree.com/blog/what-is-a-brand-inventory/

Moore, K., \& Reid, S. (2008). The birth of brand: 4000 years of branding. Business History, 50(4), 419-432. https://doi.org/10.1080/00076790802106299

Radji, D. L. (2008). Citra Merek Perusahaan Dan Loyalitas Konsumen. Jakarta, 3(200), 14.

Ranjhaa, A. (2021, March 31). Brand Elements - Definition, Types, Examples \& Selection Criteria. https://www.marketingtutor.net/brand-elements/

Setiawan, W. (2017). Era Digital dan Tantangannya. Seminar Nasional Pendidikan, 1-9.

Setyawan, A., \& Kussudiyarsana, I. (2015). Brand Trust and Brand Loyalty, an Empirical Study in Indonesia Consumers. British Journal of Marketing, 4(3), 37-47. https://www.researchgate.net/profile/Anton_Setyawan/publication/303302646_BRAND_TRUS T_AND_BRAND_LOYALTY_AN_EMPIRICAL_STUDY_IN_INDONESIA_CONSUMERS/ links/573be61008ae9f741b2d8af2.pdf

Staisch, I. (2007). A brand audit on the L'Oréal brand. Identity, December.

Steele, V. (1998). Paris fashion : a cultural history. 327.

Williams, R. S. (2019, January 25). Why Is an Internal Analysis Important? https://smallbusiness.chron.com/internal-analysis-important-80513.html 